О. І. Чепрасов /к. т. н./, Ю. М. Каюков /к. т. н/, І. А. Назаренко /к. т. н./
Запорізька державна інженерна академія, м. Запоріжжя, Україна

\title{
Дослідження нагріву високолегованих сталей у нагрівальному колодязі 3 опаленням 3 центру поду
}

O. I. Cheprasov /Cand. Sci. (Tech.)/, Yu. M. Kayukov /Cand. Sci. (Tech.)/, I. A. Nazarenko /Cand. Sci. (Tech.)/

Zaporizhzhya State Engineering Academy, Zaporizhzhya, Ukraine

\section{Investigation of heating of versachoeled steel in a heated well with filling from the poultry center}

\begin{abstract}
Мета. З урахуванням марки сталі, маси садки і початкового температурного стану металу необхідно оцінити кінцевий перепад температури у злитках сталі, що нагріваються у рекуперативному нагрівальному колодязі з опаленням з центру поду.

Методика. Дослідження виконано в процесі нагрівання високолегованих сталей у рекуперативному нагрівальному колодязі шляхом вимірювання температури у дослідному злитку.

Результати. Наведено результати термометрування дослідного злитка при його нагріванні у складі садки високолегованих сталей. Встановлено кінцевий перепад температури в злитку та характер їі зміни у процесі витримки металу.

Наукова новизна. Встановлено, що кінцевий перепад температур у дослідному злитку визначається нерівномірністю температурного поля нагрівального колодязя та складає (80...120) ${ }^{\circ} \mathrm{C}$.

Практична значущість. Використання результатів досліджень дозволяє розробити режими нагріву нержавіючих марок сталі зі скороченим на (10...20) \% періодом витримування. (Іл. 5. Табл. 1. Бібліогр.: 5 назв.)
\end{abstract}

Ключові слова: нагрівальний колодязь; опалення з центру поду; високолеговані сталі; нагрівання злитків металу; температурне поле; температура підігрівання повітря.

Постановка проблеми. Особливість теплової роботи колодязів з опаленням з центру поду полягає у вертикальному розташуванні факела і нерівномірному тепловиділенні по висоті робочої камери печі, що призводить до нерівномірного нагрівання злитків металу. У роботі наведено дані розподілу температури у злитках високолегованої сталі, що нагріваються у рекуперативних нагрівальних колодязях цього типу.

Якість нагрітого металу визначається його кінцевим температурним станом. Дослідження температурного поля злитків, що нагріваються в колодязях, пов' язані зі значними труднощами, чим пояснюється невелика кількість публікацій, присвячених, в основному, нагріванню злитків рядових марок сталі [1-5].

Підвищення якості нагрівання металу особливо важливе для підприємств, де виробляються високолеговані і спеціальні сталі. Нагрівання такого металу відрізняється тривалою витримкою та підвищеними витратами палива, тому інформація про розподіл температури в злитках дуже важлива для розробки раціональних температурних режимів їх нагрівання.
Методика досліджень. Викладення основного матеріалу. Досліджувані колодязі опалюються природньодоменною сумішшю з теплотою згоряння 6,7 МДж/ ${ }^{3}$. Розміри робочої камери 4,8×4,6 м, висота - 3,0 м. Контроль температури печі здійснюється за показаннями потенціометра на щиті КВП, на який надходить сигнал з термоелектричного термометра, встановленого у верхній частині робочої камери в спеціальній лунці. Відповідність цих показників температурі печі перевірялася в період витримки оптичним пірометром. У дослідних нагріваннях також контролювалися витрати палива та повітря, тиск у печі, температура підігрівання повітря після керамічного рекуператора і температура димових газів до та після рекуператора. Максимальні витрати палива склали $3200 \mathrm{~m}^{3}$ /год. Витрати палива та співвідношення паливо - повітря підтримувалися системою автоматичного регулювання. Тиск у лунці нагрівального колодязя підтримувався на рівні 7 Па, що відповідає заданому параметру. У процесі підготовки до досліджень було виготовлено злиток $з$ нержавіючої сталі з отворами. Маса злитка $-3,5$ т. Отвори розташовано в осьовому 
перетині злитка на трьох рівнях за висотою. У бічній стіні колодязя під час ремонту виконали прорізи, через які у дослідний злиток вводилися термоелектричні термометри. Під час дослідження прорізи герметизували.

У дослідних нагрівах злиток з отворами встановлювали поруч з пічною термопарою, температуру у злитку контролювали в семи точках (рис. 1).

Вимірювання температури виконували термоелектричними термометрами ТХА у комплекті з багатоточковим потенціометром. Також було встановлено термоелектричні термометри до і після керамічного рекуператора на димовій стороні і перед пальником у горизонтальному каналі підігрітого повітря (рис. 2).

Дослідний злиток нагрівали разом 3 технологічними злитками подібної марки сталі такої ж ваги і форми. Нагрівання проводили одразу після ремонту нагрівального колодязя. Результати експериментальних досліджень наведено в табл. 1 i на рис. 3-5. На графіках цифрами позначено дані термопар, які розташовано у дослідному злитку за схемою, що показана на рис. 1.

На рис. 3 наведено зміну витрат газу, а також результати вимірювання температури печі та контрольних точок у дослідному злитку при нагріванні сталі 15Х5М (нагрів № 1).

На початковому етапі підвищення температури теплова потужність поступово зростає. Далі процес нагрівання відбувається при максимальних витратах газу. Такий режим встановлено 3 урахуванням температури «холодного посаду» та марки технологічного металу, що нагрівається, сталь 15Х5М. Вага садки 67,6 т.

У дослідному злитку на початок процесу нагрівання температура була вищою у грані, що обер-

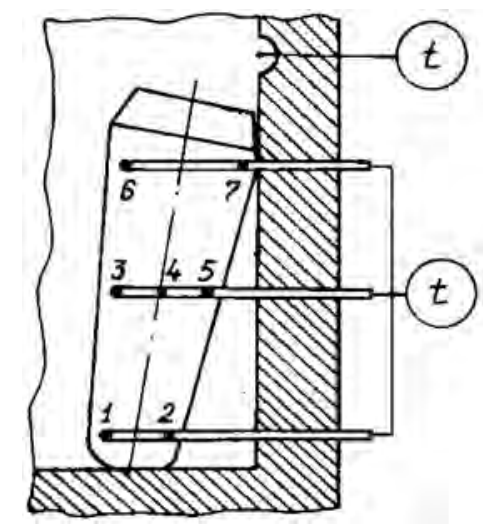

Рис. 1. Схема розташування точок вимірювання температури у дослідному злитку

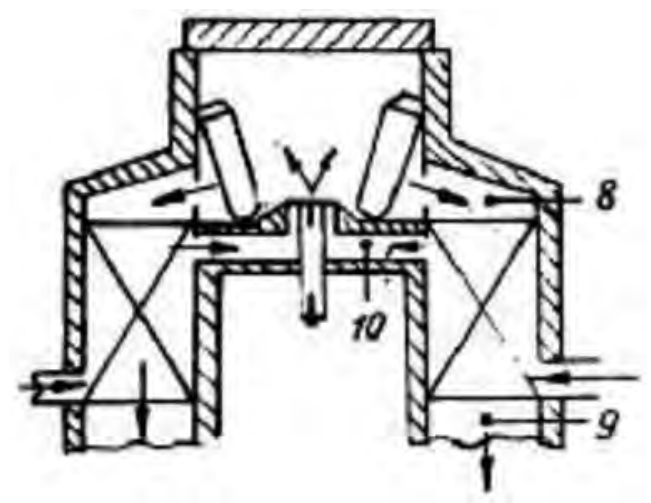

Рис. 2. Схема розташування точок вимірювання температури у робочих каналах нагрівального колодязя

нена до кладки (точки 2, 5, 7). На завершальному етапі максимальна температура була у грані, що обернена до факелу (точки 1, 3, 6). Центральна точка 4 набула в кінці нагрівання проміжного положення. Внаслідок теплової інерційності температура в злитку не може в кінці нагрівання знизитися так само різко, як і температура печі - з 1320

Таблиия 1

Результати заміру температури в дослідному злитку

\begin{tabular}{|c|c|c|c|c|c|c|c|c|c|c|c|c|}
\hline \multirow{3}{*}{$\begin{array}{l}\text { Номер } \\
\text { нагріву }\end{array}$} & \multirow{3}{*}{$\begin{array}{l}\text { Марка сталі, маса } \\
\text { садки, (кількість } \\
\text { злитків), т, (шт.) }\end{array}$} & \multirow{2}{*}{\multicolumn{2}{|c|}{$\begin{array}{l}\text { Темпера-тура } \\
\text { при посадці, } \\
\text { ॰ㄷ }\end{array}$}} & \multicolumn{8}{|c|}{ Температура в кінці нагріву, ${ }^{\circ} \mathrm{C}$} & \multirow{3}{*}{$\begin{array}{l}\text { Максимальний } \\
\text { перепад } \\
\text { температури в } \\
\text { злитку, }{ }^{\circ} \mathrm{C}\end{array}$} \\
\hline & & & & \multirow[t]{2}{*}{ печі } & \multicolumn{7}{|c|}{$\begin{array}{c}\text { в контрольних точках дослідного } \\
\text { злитка }\end{array}$} & \\
\hline & & печі & металу & & 1 & 2 & 3 & 4 & 5 & 6 & 7 & \\
\hline 1 & $\begin{array}{c}15 \times 5 \mathrm{M} \\
65,34(18)\end{array}$ & 450 & $>500$ & 1245 & 1235 & 1170 & 1250 & 1230 & 1198 & 1270 & 1182 & 100 \\
\hline 2 & $\begin{array}{l}\text { 08X18H10T, } \\
\text { 50,4 (14) }\end{array}$ & 570 & 900 & 1235 & 1207 & 1153 & 1200 & 1182 & 1152 & 1230 & 1150 & 80 \\
\hline \multirow[b]{2}{*}{3} & $\begin{array}{l}12 \mathrm{X} 18 \mathrm{H} 10 \mathrm{~T}, \\
28,0(8)\end{array}$ & 750 & 700 & \multirow{2}{*}{1240} & \multirow{2}{*}{1164} & \multirow{2}{*}{1100} & \multirow{2}{*}{1170} & \multirow{2}{*}{1140} & \multirow{2}{*}{1110} & \multirow{2}{*}{1190} & \multirow{2}{*}{1100} & \multirow{2}{*}{90} \\
\hline & $\begin{array}{l}\text { 08X18H10T, } \\
38,5(11)\end{array}$ & 800 & $>500$ & & & & & & & & & \\
\hline 4 & $\begin{array}{l}\text { 12X18H10T, } \\
49,0(14)\end{array}$ & 850 & 640 & 1240 & 1150 & 1126 & 1205 & 1190 & 1175 & 1242 & 1220 & 116 \\
\hline \multirow[b]{2}{*}{5} & $\begin{array}{l}\text { 08X18H10T, } \\
38,5(11)\end{array}$ & 630 & 570 & \multirow[b]{2}{*}{1260} & \multirow[b]{2}{*}{1160} & \multirow[b]{2}{*}{1138} & \multirow[b]{2}{*}{1240} & \multirow[b]{2}{*}{1230} & \multirow[b]{2}{*}{1220} & \multirow{2}{*}{1260} & \multirow[b]{2}{*}{1240} & \multirow[b]{2}{*}{122} \\
\hline & $\begin{array}{l}08 \times 18 \mathrm{H} 10 \mathrm{~T}, \\
14,0(4)\end{array}$ & 630 & 560 & & & & & & & & & \\
\hline
\end{tabular}




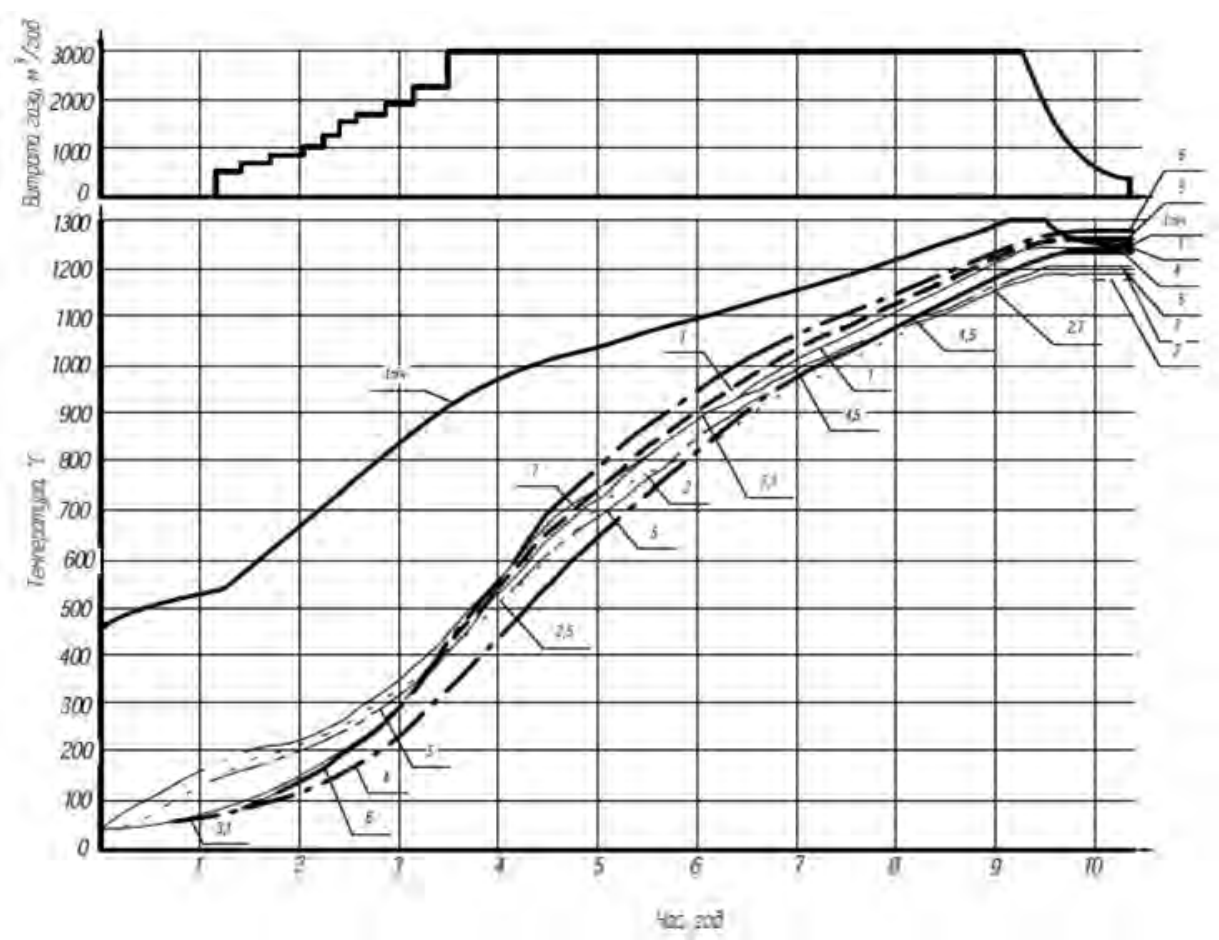

Рис. 3. Результати вимірювання температури в дослідному злитку при нагріванні садки металу 15X5M у режимі «холодного посаду»

до $1250{ }^{\circ} \mathrm{C}$. Максимальний перепад по злитку в кінці нагрівання склав близько $100{ }^{\circ} \mathrm{C}$ (точки 6, 2).

Інші дослідження виконано для неіржавіючих марок сталі (див. табл. 1).

Відповідно до чинної технологічної інструкції режим нагрівання нержавіючих марок сталі включає: 1) підйом до температури томління $1180{ }^{\circ} \mathrm{C}$; 2 ) витримування при $1180{ }^{\circ} \mathrm{C}$ протягом $1 . . .8$ годин (тривалість визначається пластичністю металу і температурою садження злитків); 3) підйом до температури томління $1240{ }^{\circ} \mathrm{C}$ для пластичного або $1220^{\circ} \mathrm{C}$ для малопластичного металу і металу з особливо низькою пластичністю; 4) витримування при цій температурі протягом 3...5 годин.

На рис. 4 наведено результати нагрівання садки, складеної $з$ технологічних злитків двох марок неіржавіючих сталей (див. табл. 1, нагрів № 3).

Через годину після початку нагрівання дослідного злитка та восьми злитків сталі 12Х18Н10Т у чарунку нагрівального колодязя досадили ще

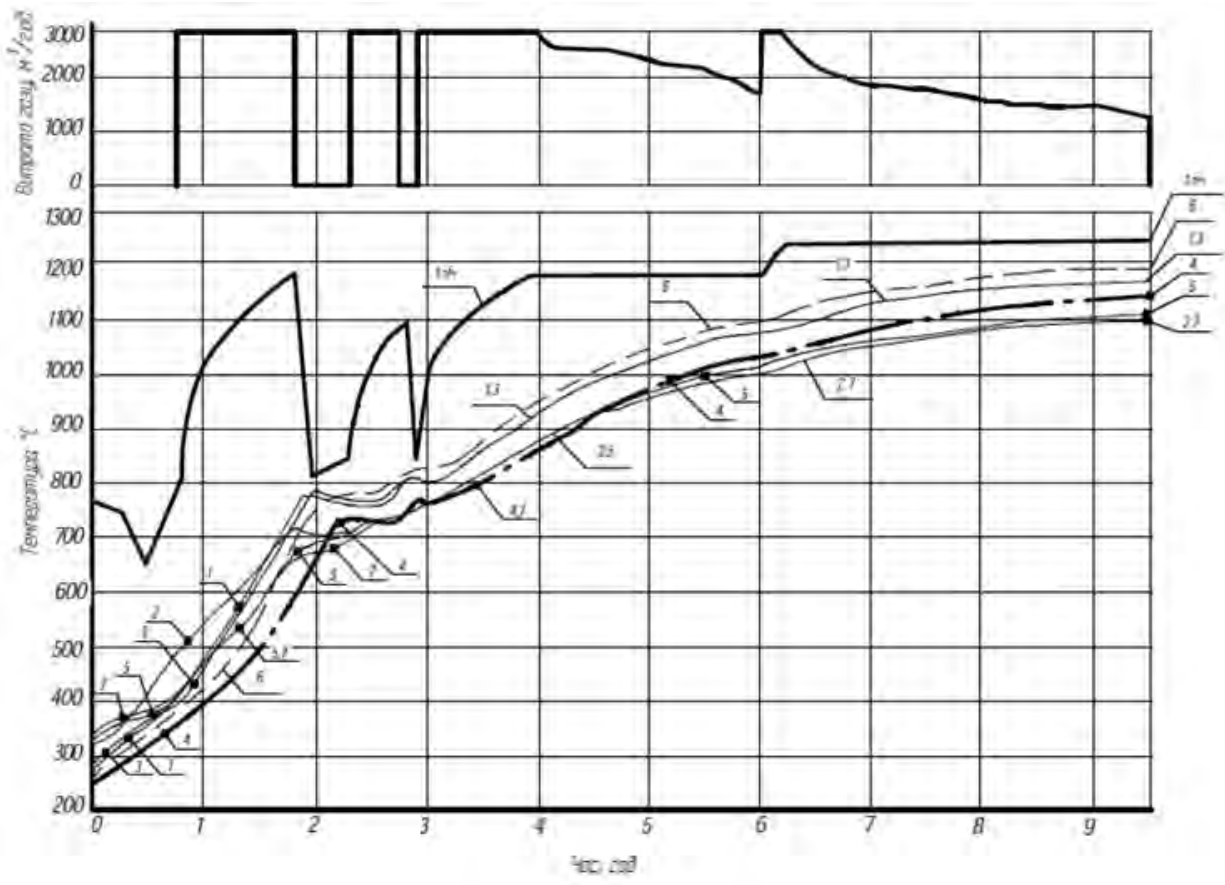

Рис. 4. Розподіл температури в дослідному злитка при нагріванні садки технологічних злитків двох марок неіржавіючих сталей (нагрів № 3) 
одинадцять злитків сталі марки 08Х18Н10Т. Злитки були рівномірно встановлені по периметру робочої камери печі. Витрати газу в період підвищення температури були максимальними і склали $3000 \mathrm{~m}^{3}$ / год, у період витримки вони поступово зменшуються і в кінці нагрівання дорівнюють $1200 \mathrm{~m}^{3}$ / год.

Протягом першої витримки при $1180{ }^{\circ} \mathrm{C}$ грань злитка, яка обернена до факела (точки 1, 3, 6), мала температуру вищу, ніж інші контрольні точки. Максимальна температура в злитка (точка 6) у кінці другого ступеня витримки при температурі $1240^{\circ} \mathrm{C}$ склала $1190^{\circ} \mathrm{C}$. Температура у центрі (точка 4) займає проміжне положення в розподілі температур у злитку, у якому спостерігався значний перепад між гранню, оберненою до факела (точки 1, 3, 6), та гранню оберненою до кладки (точки 2, 5, 7).

Характер розподілу температур у дослідному злитку в кінці витримки аналогічний результатам попереднього нагрівання (див. табл. 1, нагрів № 2), однак рівень усіх контрольних точок на $50{ }^{\circ} \mathrm{C}$ нижче. Протягом останньої години витримки розподіл температур у металі практично не змінився, а максимальний перепад між точкою 6 та точками 2,7 склав $90^{\circ} \mathrm{C}$.

Зміну в часі температури печі та температури в контрольних точках дослідного злитка при нагріванні 14 технологічних злитків неіржавіючої сталі марки 12Х18Н10Т (див. табл. 1, нагрів № 4) наведено на рис. 5. При четвертому нагріванні, разом 3 температурою контрольних точок $1, \ldots 7$, у дослідному злитку фіксували температуру пі- дігрівання повітря і димових газів перед та після рекуператора.

Витрати палива у період підвищення температури були майже максимальними і становили (2800...2900) м³ / год. У дослідному злитку протягом усього періоду підвищення температура в оберненій до кладки поверхні (точки 2, 5, 7) була вищою, ніж температура решти точок. Це пояснюється добрим прогріванням кладки колодязя перед посадкою злитків. До кінця першої витримки завершився перерозподіл температур у злитку. Максимальний перепад між точками 6 i 2 склав $80^{\circ} \mathrm{C}$. До кінця другої витримки розподіл температур стабілізувався, залишаючись незмінним протягом 1,5 год. Найвищі температури було зафіксовано у верхній частині злитка (точки 6, 7), найнижчі - у донній частині (точки 1, 2). Максимальний перепад між точками 6 і 2 склав $116^{\circ} \mathrm{C}$. Температура контрольної точки 6 у дослідному злитку відповідала на кінець нагрівання середній температурі печі по щитовому потенціометру.

Температура надрекуперативного простору (точка 8) змінювалася відповідно до зміни температури печі $t_{\text {піч' }}$ була на $(200 \ldots .250){ }^{\circ} \mathrm{C}$ нижче останньої та не перевищувала $1020^{\circ} \mathrm{C}$. Температура диму після рекуператора (точка 9) змінювалася в діапазоні (300...500) ${ }^{\circ} \mathrm{C}$. Температура підігрівання повітря (точка 10) підвищувалася з 450 до $580{ }^{\circ} \mathrm{C} \mathrm{i}$ була більш ніж на $200{ }^{\circ} \mathrm{C}$ нижче за паспортні дані $(700 \ldots 800)^{\circ} \mathrm{C}$.

Аналіз результатів нагрівання дослідного злитка разом з технологічними злитками нержавіючих сталей (див. табл. 1, нагріви № 2...5) показав як
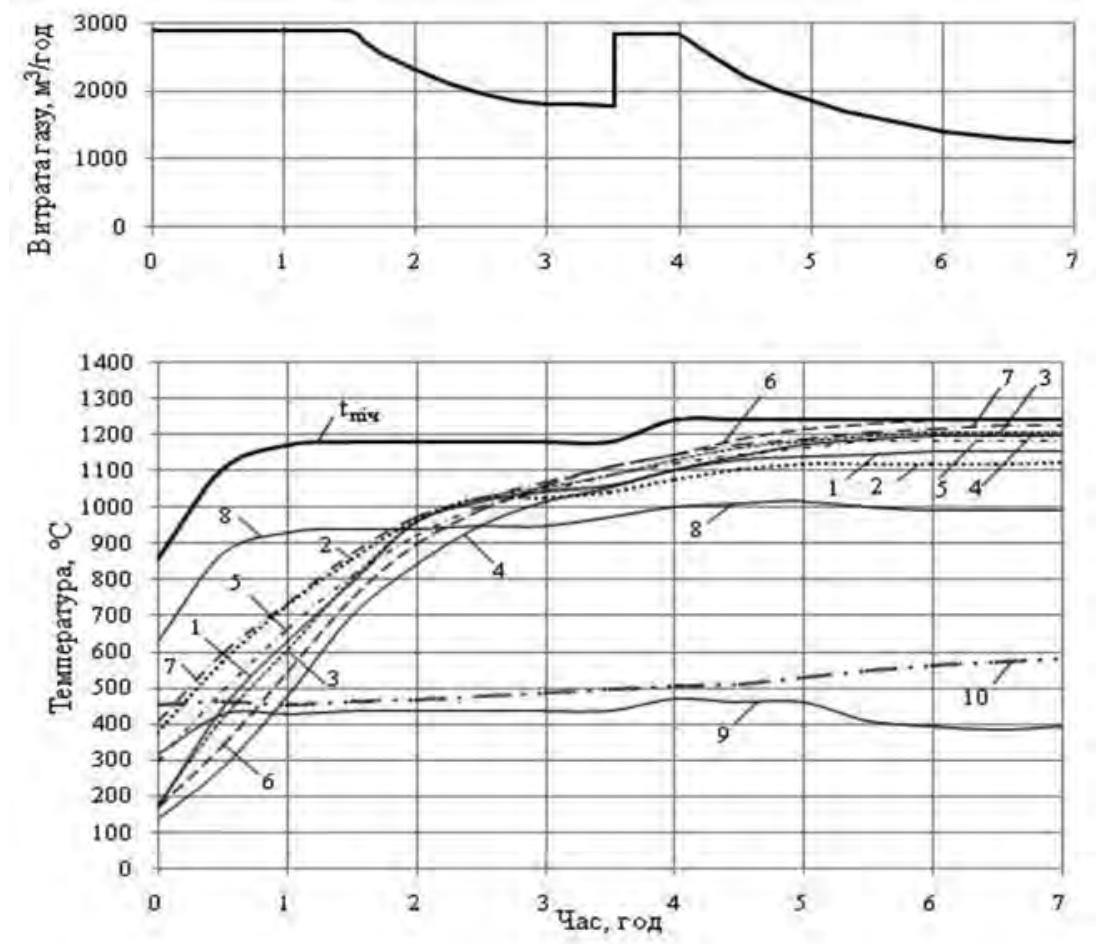

Рис. 5. Результати термометрування дослідного злитка при нагріві 14 технологічних злитків неіржавіючої сталі марки 12X18Н10Т (нагрів № 4) 
відмінність, яка проявилася в різному кінцевому перепаді температури, так і схожість, яка характеризується подібністю розподілу температури в об'ємі дослідного злитка. Відмінність кінцевих перепадів температури визначається температурним станом печі і технологічного металу при його посадці в колодязь, різницями в масі садки, а також характером тепловиділення по висоті робочої камери печей цього типу. Подібність розподілу температури визначається схожістю режимів нагрівання нержавіючих марок сталі.

Висновки та перспективи розвитку напряму. Отримані результати дозволяють зробити такі висновки:

1. Температура печі в кінці витримування відповідає максимальній температурі у злитку, який розташований близько до термопари.

2. Максимальний перепад температур у злитку становить на кінець нагрівання (80...120) ${ }^{\circ} \mathrm{C}$ та визначається нерівномірністю температурного поля в колодязі.

3. У зв' язку з тим, що на кінець витримування розподіл температур у злитку істотно не змінюється, має сенс скоротити загальну тривалість витримування для нержавіючих марок сталі на $(0,5 \ldots 1)$ годину або на $(10 \ldots 20) \%$.

4. Температура підігрівання повітря в керамічному рекуператорі в процесі нагрівання садки металу змінюється в середньому від 400 до 600 $\mathrm{C}$, що значно нижче за паспортні дані.

\section{Бібліографічний список / References}

1. Тайц Н. Ю. Технология нагрева стали / Н. Ю. Тайц. - М.: Металлургиздат, 1962. - 567 с.

Taits N. Yu. Steel heating technology. Moscow, Metallurgizdat, 1962, 567 p.

2. Аксельруд Л. Г. Нагревательные колодцы / Л. Г. Аксельруд, И. И. Сухов, В. М. Тымчак. - М.: Металлургиздат, 1962. - 236 с.

Axelrud L. G. Sukhov I. I., Tymchak V. M. Heating well. Moscow, Metallurgizdat, 1962, 236 p.

3. Свинолобов Н. П. Печи черной металлургии / Н. П. Свинолобов, В. Л. Бровкин. - Днепропетровск.: Пороги, 2002. - 154 с.

Svinolob N. P., Brovkin V. L. Furnaces of ferrous metallurgy. Dnepropetrovsk, Thresholds, 2002, 154 p.

4. Ткаченко О. О. Високотемпературні процеси та установки / О. О. Ткаченко. - Х.: Ранок, 2008. - 336 c.

Tkachenko O. O. The high temperature process of the installation. Kharkiv, Ranok, 2008, 336 p.

5. Миткалинный В. И. Усовершенствованная система отопления нагревательных колодцев при подаче топлива из центра пода / В. И. Миткалинный, В. Н. Хлопокин, В. С. Мешалин и др. / / Сталь. - 1979. - № 4. - С. 312-314.
Mitkalinny V. I. Khlopokin V. N., Meshalin V. S. Improved heating system of heating wells when supplying fuel from the center of the hearth. Steel. 1979, no. 4, pp. 312-314.

Цель. С учетом марки стали, массы садки и начального температурного состояния металла необходимо оценить конечный перепад температуры в слитках стали, которые нагреваются в рекуперативном нагревательном колодце с отоплением из центра пода.

Методика. Исследование выполнено в процессе нагрева высоколегированных сталей в рекуперативном нагревательном колодие путем измерения температуры в опытном слитке.

Результаты. Представлены результаты термометрирования опытного слитка при его нагреве в составе садки высоколегированных сталей. Установлен конечный перепад температуры в слитке и характер ее изменения в процессе выдержки металла.

Научная новизна. Установлено, что конечный перепад температур в опытном слитке определяется неравномерностью температурного поля нагревательного колодца и составляет (80...120) ${ }^{\circ} \mathrm{C}$.

Практическая значимость. Использование результатов исследований позволяет разработать режимы нагрева нержавеющих марок стали с сокращенным на (10...20) \% периодом выдержки.

Ключевые слова: нагревательный колодец; отопление из центра пода; высоколегированные стали; нагрев слитков металла; температурное поле; температура подогрева воздуха.

Purpose. Taking into account the steel grade, the mass of the set and the initial temperature state of the metal, it is necessary to estimate the final temperature drop in the steel ingots, which are heated in a recuperative heating well with heating from the hearth.

Methodology. The study was performed in the process of heating high-alloy steels in a recuperative heating well by measuring the temperature in an experimental ingot.

Findings. The results of thermometry of an experienced ingot with its nod as part of the high-alloy steel set are presented. The final temperature drop in the ingot and the nature of its change in the process of holding the metal have been established.

Originality. It was established that the final temperature drop in the experimental ingot is determined by the unevenness of the temperature field of the heating well and is (80...120) ${ }^{\circ} \mathrm{C}$.

Practical value. Using research results allows us to develop heating modes for stainless steel grades with a shorter (10...20) \% exposure period.

Key words: heating well; heating from the hearth; high alloy steels; heating metal ingots; temperature field; air heating temperature.

Рекомендована к публикации д. т. н. И. Г. Яковлевой

Поступила 20.09.2018 